\title{
The Ugandan hip-hop image: the uses of activism and excess in fragile sites
}

\author{
SIMRAN SINGH \\ Department of Music, University of Liverpool, Liverpol, UK \\ E-mail: Simran.Singh@liverpool.ac.uk; Simransingh03@gmail.com
}

\begin{abstract}
This article discusses the characteristics of image in Ugandan hip-hop with a particular focus on representations of activism and excess. Locating Uganda as a fragile site on the basis of widespread political, social and economic marginalisation, this examination considers members of Uganda's first generation of hip-hop artists, to argue that both activism and excess act in singular response to these circumstances. Finding articulation in strivings for economic freedom and social justice, the Ugandan hip-hop image reveals negotiations of histories of colonialism and of contemporary neoliberal capitalism: in doing so, it raises intersections of race and gender, informed by hip-hop's significance as a multi-billion-dollar global industry. This cross-disciplinary inquiry combines ethnomusicology with media, cultural and visual studies in dialogue with political economy.
\end{abstract}

It was late one Monday night, or very early Tuesday morning, depending on one's perspective. I was at a club, Deuces in Kansanga, Kampala, an area known for its nightlife, with bars and restaurants open through the day and through the night. I was attending the premier of the music video for A New Day. It was, I was told, the most expensive video shot in Uganda thus far. This was the latest track of Atlas da African, Uganda's best known 'rapper who raps in English' and star of the Deuces Entertainment Group, featuring Lilian Mbabazi, popular superstar and beloved chanteuse. It was also 'Hip Hop Monday', a club night Atlas hosted. I had attended several of these events and the evening is promoted by the promise that he takes the mic late in the evening for impromptu performances.

On a few occasions, I had arrived too early, that is to say, at 1 a.m., and it was an hour or so before the place became lively, which tended to happen by around 3 a. $\mathrm{m}$. Those involved with the music industry are striking in their visibility. You will find them in the best seats the club has to offer, with table service, magnums of costly liquor brands on prominent display. Crews and 'posses' are, in Kampala-speak, 'swagged out', glamorously attired and flamboyantly clad, both men and women sporting gilded fabrics and jewellery, strobe lights sparkling off sequins and chains, while revellers fill both levels of the space to capacity. Tonight, the image of Atlas was broadcast, not on television screens, but instead onto the cement walls of the 


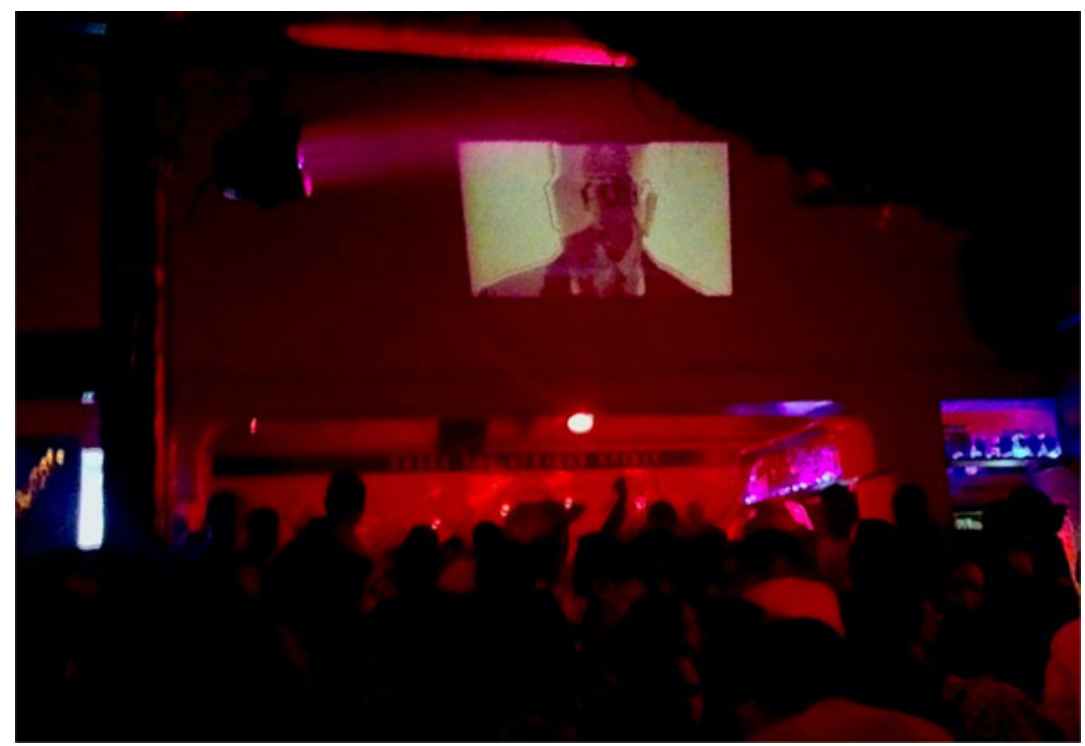

Figure 1. Atlas' video premier at Deuces, Kampala, 2014.

club through a video projector. The club did not have flat screen monitors mounted onto its walls (Figure 1).

Events at Deuces are celebrations of conspicuous consumption and raucous entertainment, occurring beside distinctly humble enterprise. Outside the venue, street vendors sell rolex, rolled flatbread and eggs, nyamachoma, grilled meat on coals, boiled eggs, and Rex and Sportsman cigarettes. The sides of the road bristle with boda-bodas, motorcycle taxis, while luxury SUVs and sportscars jostle for parking. Nightlife in Kampala is plentiful and exciting. Elucidated by a sentiment that I came across often and spoken in different ways, 'If a man hasn't had his lunch because he only has money for a beer in the evening, he doesn't want to be reminded of it. He wants to forget' ${ }^{1}$ the attention is on dancing, drinking and entertaining. Music serves as both backdrop and focus to these musical and social activities.

This juxtaposition of plenty and penury led me to question the uses of activism and excess in Uganda's hip-hop scene as a form of civil society (Singh-Grewal 2018). This article provides a further interrogation, wherein the Ugandan hip-hop image is a constructive act of performance: comprising musical and social narratives in the public sphere, signified through modes of fashion, in personal stylisation, supported by a symbolic language, and propagated through promotional imagery. Based on my own experience as a branding designer conducting ethnographic research in Uganda, ${ }^{2}$ this critical approach will show how the Ugandan hip-hop image inculcates themes and motifs in dialogue with hip-hop as a global cultural phenomenon,

1 Personal conversation with an informant who preferred to remain anonymous, 5 December 2014.

2 The ethnographic method is used along with branding design as collaborative process, including album covers and the creation of promotional imagery, supplemented by data gathered over interviews and from participant-observation in social and musical life. Fieldwork included two excursions, the first at the end of 2104 and the second in 2015, conducted over my doctoral research project. My association with Uganda began in 2011; this project reflects a period of 6 years living and working in the country, 
in relation to lived experiences specific to Uganda's past and present. I draw on a diverse range of scholarly thought, including Houston Baker Jr's theorisations on deformation and mastery in black popular forms, forms and renditions of Du Bois' double consciousness, and the uses of image in the post-colony, to show how the Ugandan hip-hop image shows a negotiation of social and economic fragility. Dual images of activism and excess articulate strivings for economic success and social justice, wherein symbols of acquisition may be apprehended as aspects to aspire to, or to discard in indictment. From this emerges a wider arbitration of the inequities of capitalism in the present, borne by a colonial past.

\section{Frameworks: oil and water}

Uganda's musical cultures, including hip-hop, occur in a site of profound social and economic rupture. Political turmoil followed closely after Uganda's independence in 1962, with the advent of military dictator Idi Amin in 1972 and his successors in the 1970s and 1980s. Hundreds of thousands of Ugandans lost their lives or were compelled to flee. The year 1986 saw relative peace with the start of Yoweri Museveni's regime. In 1987, Alice Lakwena, a self- proclaimed prophetess, launched an insurgency called the Holy Spirit Movement in northern Uganda, and in 1988, Joseph Kony, took over what became the Lord's Resistance Army. A 17-year-long civil war between the Lord's Resistance Army and the Ugandan army had devastating effects in the north, leading to long standing post-conflict scenarios. In the present day, economic and social fragility is characterised by this history of prolonged conflict, political authoritarianism and structural violence in the form of extreme poverty, deeply contested resources and a prevalence of HIV/AIDS, each exacerbated through corruption and a lack of employment opportunities and basic infrastructure such as healthcare (Dolan 2013; Lomo and Hovil 2004; Mamdani 1997; Weigratz 2010; Finnström 2008). Uganda's conflicted relationship with capitalism is shown through issues with development, a legacy of neoliberal structural adjustment programmes placing the market as moderator and stabiliser of economic and political processes. A dependency on external funding is visible in the preponderance of headquarters of international development organisations in the capital city, Kampala, and in signages of outreach programmes in towns and villages, representing therefore the charity 'business' and the development 'industry'.

Ugandan hip-hop, therefore, like the global phenomenon of hip-hop, appears at a convergence of 'dehumanizing neoliberal globalisation' (Rollefson 2017, p. 3) of which capitalism is part, alongside the 'human realities of postcoloniality' (Rollefson 2017). Critically situated by hip-hop's significance as a multi-billion-dollar global industry (Perry 2008, p. 295; Murray 2004), the genre has emerged as a successful symbolic instrument which combines and normalises preoccupations of activism and excess, framed as conscious and commercial (Chang 2007; Murray 2004; Perry 2008; Rose 1994). Powerfully imaged, hip-hop extends successfully from music into film, television and corporate merchandising, in a global flow of its own (Lipsitz 1994), mediated and propagated by capitalism and attendant corporate

including fieldwork conducted in conflict reportage and radio during my MA in Media and International Development. 
cultures. As Derek Conrad Murray states, 'global capitalism and revolution are like oil and water, but in hip-hop they're akin to Siamese twins' (2004, p. 5). This is a thought presciently put forward by Angela McRobbie, who states that 'Dallas is destined to sit alongside images of black revolt' (1994, p. 21) predicting, in fact, the success of television shows such as Empire, which places hip-hop as a central theme around which is arranged imagery of lavish material success.

The use of image in Uganda's hip-hop scene is mapped through the stories of Gasuza Lwanga, Atlas da African and Silas 'Babaluku'. In their mid-forties, they are local celebrities, and are seminal figures among Uganda's first generation of hip-hop artists. Formative encounters with hip-hop occurred in North America as adolescents in the early 1990s, a result of their families' forced migrations during the Amin years. They returned to Uganda in the late 1990s, at a time of relative peace and economic liberalisation, and the development and distribution of media capabilities after decades of civil conflict. The emergence of an urban middle class, and the liberalisation of and subsequent growth of the mediasphere, particularly FM radio and cable television (Ssewakiryanga and Isabirye 2006), informed the emerging popular music industry (Ssewakiryanga 1999, 2004), setting the stage for the emergence of Ugandan hip-hop.

While popular genres such as local kidangali and Jamaican-influenced dancehall dominate the charts, Gasuza, Atlas and Babaluku, alongside established commercial hip-hop stars such as Navio, Eddie Kenzo and GNL Zamba, remain influential in the contemporary cultural context of the Ugandan music industry as 'original' practitioners and proponents of hip-hop and its beginnings in Uganda. It is important to note that, while this article focuses on three male hip-hop 'elders', as they are often referred to by younger rappers, the popular music industry numbers several influential and well-loved female stars. Established musicians such as Mys Natty and Lilian Mbabazi straddle genres such as soul, R\&B, reggae and hip-hop with ease, and have collaborated with these elders (Singh forthcoming). The hip-hop scene, both past and present, includes adept female rappers: Tshila, a member of Bataka Squad, Uganda's first hip-hop ensemble, of which Babaluku was part, Lady Slyke, KeKo and MC Yallah to name a few. This is bolstered by a number of music festivals in contemporary Uganda. Prominent among these is the critically acclaimed and commercially successful Nyege Nyege festival, which has furthered cutting-edge electronic dance music from Northern Uganda such as Otim Alpha's Acholitronix. As such, the Ugandan hip-hop image as represented by the three individuals discussed here provides a view that is characteristic of the hip-hop scene in general and the preoccupations that outline and inform it. Against this backdrop, the next three sections provide an interrogation of the Ugandan hip-hop image as exemplified by Atlas, Gasuza and Babaluku.

\section{'Never did crime, never did time' and 'gangsta' excess}

Prince Eddie Igimura, or as he is better known, Atlas da African, is crown prince of the Ankole kingdom in Uganda. A Google search shows images of him performing on stage, side by side with those of him posed in a suit next to President Museveni. Crown prince is titular and has no authority in matters of governance. Atlas is a celebrity across all of east Africa and is appreciated as a performer who raps in English. From this, Atlas can be viewed as a central signifier to a cultural fabric of consumption in Uganda's hip-hop scene where he becomes one of Taylor's 'stars 
(and) megastars' (2015, p. 15), whose success allows them to live and represent the forms of attainment valorised in this milieu. Like Gasuza, Atlas is often featured in local tabloids, similarly fashioning an image of excess that mirrors 'gangsta' tropes found in mainstream American hip-hop.

Eddie came of age in Canada. Because of his and his family's migrations in the Amin era, he displayed a knowledge of places his peers had no idea existed, and so, they called him Atlas. This story now forms part of his Ugandan hip-hop image. Newspaper reports suggest that Jay-Z, the hip-hop megastar, acknowledged his skills at a rap battle in Toronto, and industry gossip includes a collaboration with Canadian superstar Drake. ${ }^{3}$ A collaboration with cult NYC rappers, Smif-nWessun indicates a musical career that showed some promise. Shot in Kampala and New York, the video is directed by Gasuza. Atlas raps about his family, 'Daddy was a general, Idi Amin put a hit on my dad, my bloodline's gone, but I'm living life to the fullest', while also expressing disillusionment with present day Uganda in statements such as 'our government is failing us'. ${ }^{4}$ In his music, he talks about his struggles of displacement and then criminality in lyrics such as, 'never did crime, never did time, never owed a hundred grand before nine' ${ }^{5}$ A promotional picture shot by Gasuza shows him seated on a bed in a plush apartment. On one side is a female figure, her face obscured by bedclothes, and on the other, is an AK-47 rifle, dollar bills fanned out next to it, all evoking a 'gangsta' rap image.

Atlas' biggest hit at the time of field research was 'Ahh Ahh Ahh', a collaboration with Ugandan dancehall superstar Chameleone. ${ }^{6}$ The lyrics, featured in Table 1, celebrate a personal narrative of excess, in contrast to a stripped-down beat, reminiscent of commercial hip-hop in the early 2000s. This minimal sonic format serves well in the showcasing of Atlas' flow, which is compelling, as well as the hook or the chorus.

Atlas' image finds representation in the cadences and imagery of 'street' narratives (Anderson 1994). Such representations are persuasive as 'rhetorical resources for the discursively captured and occupied sites of urban survival and conquest' (Watts 1997, p. 44), pointing thus towards negotiations of economic success in spaces of social fragility. In 'Ahh Ahh Ahh', we see an evocation of the 'street', ostensibly evoked from Atlas' time in Canada. Within the hip-hop scene, these 'hardcore' narratives are received as 'real' or representative of his experiences in North America rather than bogus posturing. At the same time, this track is a clear celebration of life in Kampala. He raps about upmarket neighbourhoods comprising restaurants, clubs, foreign embassies and the headquarters of large international aid organisations. Signified in a vocabulary of brands of cars, liquor and clothing, Atlas' image revels in the spoils of economic success, embellished by the names of casinos and affluent neighbourhoods, of liquor and clothing, and in the recounting of criminality and street credibility. At the same time, the calling out of neighbourhoods, activities, brands and successes he enjoys informs the listener that his struggles are now overcome because he is home.

Atlas' hip-hop image, not least because of his own standing as crown prince of the Ankole kingdom, remains in the domain of privilege and profitability. Atlas is the visible star of the Deuces enterprise, which comprises a label, nightclub and recording

\footnotetext{
${ }^{3}$ http://ugblizz.com/ugandan-rapper-atlas-recording-a-song-with-drake/, UGBlizz, 24 January 2016.

4 https://www.youtube.com/watch?v=O1vaEDWgyZk, published 27 April 2011.

5 https://www.youtube.com/watch?v=AuemUALnw3c, published 7 March 2014.

${ }^{6}$ https://www.youtube.com/watch?v=54EHmfPgWC4, published 9 Mary 2014.
} 
Table 1. Atlas da African - 'Ahh Ahh Ahh ft. Chameleone', 4 March 2014 - DEG. Available on Apple Music, lyrics shared courtesy of the artist

[Verse 1]

I get a funny feeling when am forced to deal with middlemen

Wait for me fly you're being senior citizen,

Uganda life's real yeah am swerving on the rail

With too bad bars and high heels and miniskirts (fly)

Past Kabalaga on Gabba headed to Deuces

Champagne flowing like water go ahead and order (nothing)

Dressed in Versace these haters they can't stop me

Mad coz when I pull up the Rolly his shawty watch me,

Kampala am a Capone

Already blew 1000 a day what can you say? (Nothing)

The club is on Smash, UG girls got bodies

Fuck a Buggatti, I woke up in a new punani

So where the whole club last night was made real

Hangover, headaches, water and Advils

Lean with it rock with it lean with it

Lean with it rock with it pockets gat 20 stacks

(Chorus)

I see di time or they flashing on the bling bling bling

I've been proposed too but never took the ring ring

VIP sitting will be treated like the kings ahh ahh ahh

In every way see mi champagne the bottle pops

Haters hating but they forced to give it props

He make his music so they can hear the tops ahh ahh ahh
[Verse 2]

Back to downtown from Owino up to Kololo

Catch me out Simba Casino spending pesa

Solo, gambling and scrambling for paper

Balling like the Lakers am Kobe you cannot control me

So rock on ice, wrist on ice

You only live once nigga this is my life

Fresher than a shower, money and the power

Used to struggle, used to hustle, now it's bottles by the hour

Dedication, hard work, integrity and loyalty success soon come

Hope the money doesn't spoil me

Addicted to the cash, fainted for the dollars

Deuces Entertainment Young hustlers discarded

Supermodels by the dozen

You're really ain't nothing

Be careful who you touch

I put ya body in the ocean

Beef is like lasagne it comes in many layers,

The game never changes homie only the players

(Chorus)

\section{[Verse 3]}

Black boy stunting hard with all his cars foreign

Had the white on the grill

I felt like George Foreman, fourth quarter I was Jordan

My whole team scoring

Called papi made a purchase early every three mornings

Jay gave me props but it didn't mean much

I was still out the next night selling my stuff

Waiting on a deal and I talk of records

Platinum make a mill

I was trapped before rapping

Duffle bag boy blue jeans and white T's

Like the Tower of Pisa, my chopper make you lean

Don't believe me ask God I went hard

Worldwide famous, pictures with the stars

Did the Hummers and the summers,

Crashed a few Benzes

Lost a few friends got back a few Exs

None of y'all rappers did it like me

First day out of jail was in an SUV

(Chorus) 
studio. His image is bolstered by the support and presence of other members of this entourage, in musical and social life. The imagery of the gangsta rap life-world that Atlas so adeptly uses points towards what Watts refers to as 'spectacular consumption' (Watts 1997, p. 44), where artists and audiences attempt to live large in a manner that behoves the hip-hop stars they draw inspiration from. This is similar to Lipsitz's successful popular music masquerade, a performance of the 'street'. This image is potent in representation to those who behold it, as it is a means by which is conveyed success in the face of struggle, not unlike the hip-hop moguls in urban America's hip-hop mediascape (Smith 2003). 'Bling-bling', as the chorus of 'Ahh Ahh Ahh' goes, and an accompanying garish display of wealth is one aspect of hip-hop's celebration of narcissistic excess, projected through imagery that places sexual pleasure and consumer purchases at the centre of the social world (Lipsitz 2007, p. 180).

In the adoption of these motifs, Atlas' image favours a problematic masculinity. This could be ascribed to a coming of age in the 1990s at a time when gangsta rap rose to commercial and cultural dominance in the USA and elsewhere. Hip-hop has been fêted for the articulation of hidden transcripts of black cultural expression, but gangsta rap in particular makes hip-hop a contested space that displays brazenly commodified representations of women and female sexuality (Cheney 2005; Bradley 2015). Atlas' image and the gangsta tropes that embellish it reflect mainstream hip-hop's social, political, economic and cultural values rather than transgression (Cheney 2005). These values encompass the tacit commendation of conventional gender roles, heterosexism and the valorisation of capitalist acquisition and conspicuous consumption. They show a complicity between wider consumer exchange relations and cultural production, in the form of 'the plantations' of gangsta rap and capitalist patriarchy (hooks 1994, p. 122), wherein violence and misogyny are approved of and materially rewarded.

In Uganda, like elsewhere, women and girls are less likely to receive an education, find sustainable employment and therefore establish economic stability and exercise social agency, aspects that, as a female researcher pursuing a doctorate at the time, I was uncomfortably aware of. Notable scholarly reckonings of Uganda's uniquely complex gender issues are framed by concerns of development, acknowledging the effects of HIV/AIDS, war and post-conflict situations (Annan et al. 2011; Okello and Hovil 2007), education (Björkman-Nyqvist 2013; Mirembe and Davies 2001) and the rural economy (Katungi et al. 2008; Canagarajah et al. 2001). A detailed interrogation of these issues is beyond the remit of this article. However, it is worthwhile to note that these situations are equally the result of Uganda's own history of violence, which, as stated in the introduction, informs the birth of the hip-hop scene in particular and the popular music industry more generally. From this perspective, Atlas' image and the performances that inform it can be implicated in an abnegation of gendered rights and responsibilities. Moreover, like the 'cultural dimension' of religion (Geertz 1973, p. 89), a vocabulary of signs and symbols shows how neoliberal capitalism can be conceived of as a global cultural system overriding all actors within it (Taylor 2015). This dominance then allows for the conception of a consonant global mainstream wherein capitalist acquisition and conspicuous consumption occur side by side with gender-based discrimination. More significantly thus, in sites of social and economic fragility such as Uganda, they accordingly emphasise a similar abnegation exemplified by neoliberal capitalism, traversing gender alongside race, social-political agency and class in the Global South.

In actual fact, there is nothing truly 'gangsta' about Atlas. On the contrary, he is thoughtful, soft-spoken and affable in person, his demeanour marked by a polite 
regard for those he interacts with, including in our discussions and interviews, and at recording sessions I observed. Nor has he reached the rarefied spaces of celebrity and wealth that Jay-Z, a rapper that he holds in high esteem, compels. In the mirroring of these proclivities, however, Atlas is fashioning an image that seeks to elevate himself as hip-hop artist through his music and lifestyle choices. This exhibition is only spectacular when viewed in contrast to 'the ranks of the downtrodden' (Smith 2003, p. 680), from whence such a figure has emerged or has claimed to emerge from. Atlas does not claim to emerge from the downtrodden in Uganda. However, his is an incongruous pairing of privilege and suffering. His image is inflected by motifs of hardship, caused by his family's rank in Uganda, which veered from powerful to persecuted and back again. In the articulation and enactment of this gangsta image, he becomes a symbol of success rather than social alienation, an aspect which is in no way hindered by his position in Uganda, as a man, a prince no less, enjoying relative influence and affluence in contrast to the wider populace.

\section{'Fake-ass bling' and material excess}

Gasuza Lwanga is a musician and rapper, and an accomplished fashion photographer and music video director. These attributes have engendered several professional associations, particularly with Atlas da African, who I discuss in the next section. Gasuza is a well-known fixture in Kampala's music and nightlife. He has founded production companies, including Market Makers and Rogue Elephant, but only had a break-out hit of his own in 2015, with the track 'Sober'. Gasuza's career spans three decades and includes a stretch at the iconic Def Jam records in New York in the 1990s; he was part of an ensemble that opened for well-known artists such as The Roots and De La Soul. In his words, 'the other act got signed, we didn't'.

He says on many occasions, 'I am hip-hop' on the basis of his love and identification of the genre. Our interviews included vivid anecdotes of encounters with hip-hop celebrities, some at the height of their success and others at the cusp of it, such as 'that time when Kanye West waited for days at the reception', mixtape in hand, parties with Sean 'Puffy' Combs when he was dating Jennifer Lopez, being in a rap 'cypher' with RZA of Wutang Clan, a meeting with Tupac Shakur at a recording studio and a regard for the New York rapper, Sean Price. These reminiscences were filled with humour and colourful descriptions, all of which provided an extremely enjoyable insight into Gasuza's own love for the genre and his relationship with it. Gasuza refers to a particular piece of jewellery he favours as 'fake-ass bling', which he wears to look, in his words, current. This is a shiny gold chain, punctuated by medallions with the Versace medusa head, a counterfeit reproduction of the fashion house's brand identity. All the same, it is heavy, finely wrought and altogether a covetable ornament. This piece of jewellery is an integral part of his image, and one that has a particular capacity to evoke and invoke a lifestyle, a visual style and a fashion statement all in one. In its flashiness, it a sly and humorous critique of his image. To him, it is exactly what he said, 'fake-ass bling'. Made in China, these pieces of costume jewellery are not inexpensive in Kampala. To put it simply, everyone knows it is fake, but everyone also knows it is expensive.

\footnotetext{
7 Interview, 15 November 2014.
} 
As Stuart Hall (1993) states, a repertoire of style, which might be considered to be 'the mere husk, the wrapping, the sugarcoating on the pill - has become itself the subject of what is going on' (p. 109). The hip-hop image in Uganda, like elsewhere, points to the political economy of the sign (Lash et al. 1993; Baudrillard and Levin 1981) where material goods and their representations, such as brands of consumer objects and commodities, and the lifestyles and choices they symbolise, negotiate wider social and economic formations. Uganda is a poor country, in spite of displays of conspicuous consumption one might encounter in nightclubs. Objects such as Gasuza's chain serve as tangible representations of economic success, acting in concert with the imagery of mainstream hip-hop. Incongruous against the poverty one encounters in everyday life in Uganda, Gasuza's image, embellished by this chain, is a hip-hop 'bluff', showing us a post-colonial performance of 'the superior person one would embody all the time if one had the money for it' (Newell 2012, p. 1). The chain is a symbolic projection of wealth and currency, made doubly so by its faux glamour, understandable as a symbol of aspiration to because of its incongruity. Its power lies in the 'figurative logic of the mask ... a kind of visual grammar informing the work of image-making illusions' (Newell 2013, p. 20), manifesting in contemporary public performances. In this milieu, Gasuza's hip-hop image performs and represents 'intermeshed cultural logics' where local and often, urban 'performativities merge with anxieties over authenticity and imitative reproduction at the heart of capitalist economies' (Newell 2013, p. 140). To the Comaroffs, such displays represent the contradiction of the post-colony, and are associated with a 'counterfeit modernity, a modernity of counterfeit' (Comaroff and Comaroff 2006, p. 13).

It is worthwhile to note that the anxiety around expression in capitalist spaces is not limited to the post-colony: Jameson's (1984) indictment of the superficial as indicative of a depthlessness or waning of effect in the form of post-modern pastiche holds a similar tension. This is 'blank parody' devoid of emotive capacity and creative ingenuity. Balancing this anxiety, an appropriate contextualisation suggests that 'the performance ... mediates one of the prevalent of all antimonies of cultural investigation - creativity and commerce' (Baker 1987a, p. 9). In other words, the popular music performer is recognised for his or her masquerade and rewarded with monetary inducements and cultural influence in the recognition of this efficacious performance (Lipsitz 2007, p. xviii). This performance encoded into Gasuza's image holds yearnings for success, framed against the terms of tremendous celebrity and material success that the hip-hop stars he met and worked with in his youth in New York enjoy. Hall's 'sugarcoating' of performance in this case, is the adoption of counterfeit jewellery as an authentic representation of success. Gasuza's image is a piece of hip-hop performance that serves as a demonstration of cultural knowledge and taste, cast in the modes and fashions of mainstream hip-hop. The image, where this chain is a confection, therefore, becomes 'a positive and constructive act ... no longer in the realm of the poser but rather of the performer' (Newell 2013, p. 140). Gasuza is aware that his image owes itself to the power of representation, rather than its weight in gold, or gilt as the case may be. Gasuza is not a hip-hop megastar such as the comportment of which he emulates, nor the celebrities he reminisces about. In this capacity, the performances encoded into Gasuza's image serve as demonstrative acts, displays of potential. Image acts not as concerted deception, nor a sleight of hand: it is a means to draw the viewer into the performance of economic success in the hip-hop context, in contrast to fragility in the social and economic domains. Allowing for an appreciation of this image in the Ugandan 
context, a similar reflexivity of performativity underlies framings of both material and gangsta excess. This performativity is neither a re-enactment of tradition using symbolic objects of progress (Friedman 1994) nor an associative assertion (Ferguson 2006). Instead, it is a constructive act of negotiation, where conceptual forms of value such as logos and brands, their meanings and uses, stand reimagined in local contexts.

Nonetheless, rewards for these performances take tangible form. I was in a taxi with Gasuza, driving through Muyenga, an affluent part of Kampala. Telling me of the success of his new track, 'Sober', ${ }^{8}$ he leaned out of the window and waved at boda drivers parked on the side of the road, making sure his chain was visible. They immediately recognised him, and yelled back, 'African Sober'. This is an ironic moniker, as he has featured in tabloids such as Red Pepper, a publication known for the luridness reportage of public figures. Demonstrating local identification, this recognition is indicative of success and means far above those compelled to drive motorcycle taxis for a living. In this milieu, Atlas and Gasuza appear to revel in the spoils of the Siamese twinning of hip-hop and capitalism that Murray discusses (2004), in the form of jewellery and in the imagery of a sometimes violent and usually decadent urban lifeworld. Whereas Gasuza and Atlas project images of excess and celebrity, Babaluku shuns these aspirations entirely in the construction of his Ugandan hip-hop image.

\section{'Give them a food programme, an education programme, everyone got you a programme': the image of activism}

Silas 'Babaluku' is one of the founders of the Lugaflow 'movement'. 9 The word comes from Lugha, which means language in Swahili, and is a play on Luganda, the principal language in central Uganda. Lugaflow focuses a Ugandan hip-hop sound and narrative in support of social justice. Babaluku's work has been met with critical acclaim. He has been the subject of other scholarly work (Ntarangwi 2009) and is often referred to as Uganda's very first rapper, mentoring several successful local artists through the 1990s to the present day. Babaluku established the Bavubuka Foundation: the word Bavubuka means youth in Luganda, and it is the longest running hip-hop organisation in Uganda. Initiatives include Uganda's Annual Hip-hop Summit in Kampala, the first of which was held in 2003. The foundation has a number of enterprises such as Bavubuka Scholarship Fund, Bavubuka Indigenous Hip-hop Entrepreneur Fund, Bavubuka Kids for Kids Indigenous

8 'Sober' - Gasuza; published by Rogue Elephant Creative, 14 May 2015. https://www.youtube.com/ watch?v=BU3JgZuOuSU

9 The 2007 film, Diamonds in the Rough, documents this Ugandan 'hip-hop revolution' and features Babaluku while he was a member of the Bataka Squad. The word 'Bataka' means native. Formerly the Bataka Underground, the group was formed by Babaluku (a.k.a. Sniperous MC), Saba Saba aka Krazy Native and Big Poppa Momo MC. Founded in the mid-1990s, it was one of the earliest hip-hop groups in Uganda, with the three founder members born and raised in Kampala. The film showcases this collective and their music, which addressed the 'daily struggles and triumphs of African life'. This was part of an homage to African culture paid through the use of native language and musical references to traditional music and drumming, all set within the globally appreciated musical framework that hip-hop provides. The agenda is two-pronged - to speak about issues that affect the people and to get the new sound heard out of the country. Talking about 'what people say on the street', it is a way of empowering those who's voices are not heard. 
Hip-hop Program and the UG Hip-hop Archivist. According to the website, this nonprofit organisation sees its mandate as believing 'in connecting youth with music and the arts, [to] transform lives and unify diverse communities. We are dedicated to creating spaces and educational programs that will nurture and empower a new generation of leaders in Uganda and all of Africa, who will use their voices to communicate positive messages and affect positive change in their communities and the world'. ${ }^{10}$ The vison is clear - however, it has been difficult to gauge the effects of these initiatives beyond the hip-hop scene in terms of the goal of widespread change.

Babaluku maintains a compelling image in his approach to Ugandan hip-hop and its uses, in the form of a hip-hop 'practice'. Babaluku's particular focus is on activism in challenge of unemployment, poverty and corruption, each propagating socioeconomic fragility in Uganda, while simultaneously indicting histories of colonial violence and continued capitalist exploitation. He shared his motivation of 'going back to the source', ${ }^{11}$ meaning Uganda and the continent of Africa, where (we) 'keep coming together, bringing things together' in hip-hop and in life. Citing the 'ideology and formation' of thinkers such as Marcus Garvey and his belief of repatriation and return to Africa, and of political leaders such as Patrice Lumumba and his role in erstwhile Zaire's independence struggle, Babaluku situates his activist hip-hop image in knowledge of African history and identity.

In doing so, the activist image reveals understandings in the context of 'Knowledge of Self', or the 'fifth element' of hip-hop (Chang 2007), an aspect that I discussed with all three case studies in some detail. Knowledge of Self alludes to an understanding of one's individual worth and place, and a critical consciousness about black identity in relation to histories of racial oppression and exploitation. Only from this consciousness within and personal transformations engendered thus could one 'overstand', that is 'comprehend and confront the injustice of world by manifesting one's power' (Chang 2007, p. 106). Babaluku stands against Africa's continued marginalisation, begotten, in Babaluku's view, by colonialism and inequalities of global capitalist flows. The Ugandan activist hip-hop image is thus conceived in the recognition that formulations and constructions of knowledge have originated from spaces of power and privilege for a few, in a form of violence enacted upon the colonised (Fanon et al. 1963). This understanding is embodied in his statement, '(we think) our voices have no power because there are no powerful people to tell us we are powerful'. This is because of 'the past 52 years of colonial mentality, (and) no beauty in being anything that looks like you ... being black is ugly, (you) work as a servant, (you are a) third class citizen'. Indicting the imbalances of so-called development initiatives, he says one is given 'false information. (You) still look at your country as an ugly country ... the system you work in does not instil a sense of pride, (or create) sustainability'. He says, instead 'we are told give them a food programme, an education programme, everyone got you a programme'.

Babaluku's image finds inflection not in 'fake-ass bling', but dreadlocks down to his waist. He and the young men and women at the Bavubuka foundation wore T-shirts printed through the initiative which were emblazoned with legends such 'Power to the People' and 'Spoken Truth', along with Zulu Nation medallions and

10 https://www.facebook.com/BGlobalIndigenousHipHop/, accessed 13 April 2015.

1122 December 2014, other quotes included from this interaction. 
African print tunics. Of particular ubiquity were the Rastafarian colours of red, gold and green, which featured prominently on wristbands and as detailing on loose fitting denim. Symbols such as dreadlocks and the red, gold and green of Rastafari, are all deployed in the evoking of an image of hip-hop in the specific context of an ideal of Africa. Signalling associations with Pan-African consciousness and pride, these representations are not unlike renditions found in African American hip-hop such as in Afrika Bambata's name and the Zulu Nation organisation mythologised in hip-hop's origins in the Bronx (Chang 2007).

Babaluku's hip-hop image focuses issues of race and oppression within the specific Ugandan context of civil war and forced migrations. His first visit to Uganda was in 1995, at the age of 14 for his father's funeral. He says, 'I grew up in a generation that was stripped of language, man, I (felt like I) really don't belong nowhere'. Here, Babaluku echoes Fanon, who states that being colonised by a language has larger implications for one's consciousness: 'To speak ... means above all to assume a culture, to support the weight of a civilisation' (Fanon 1952, pp. 17-18). Speaking about his return where his dreadlocks were met with disapproval at the airport, he feels that 'even my own people don't like the way I look when I am coming home'. Later, coming back to Uganda was 'my last option'. After '11 years of going back to the concrete jungle, Africa was an escape for me, I was tired, I couldn't push anymore, I felt like I was failing at everything'. Nevertheless, his return facilitated a reconnection with a 'chunk of Africa';12 through hip-hop, he 'connected to the music scene ... clubbing with a crew of 20 '. He shared how these were, 'formative experiences, [of] fighting to be, fighting to fit in, [means that] now I am comfortable anywhere'.

In its concerns and articulations, Babaluku's activist image in Uganda aligns with the historical tradition of black nationalist discourse, within which hip-hop circumscribes a counterdiscursive masculinist Afrocentric ideal, signifying power thorough authenticity and allegiance (Cheney 2005; Dyson 1995). Uganda, like elsewhere in Africa, shows a legacy of gender-based inequites rooted in colonial practices of accumulation with relevance to labour, value and production (Sahle 2008). Like Gasuza and Atlas, his image is marked in a fundamental fashion by his own lived experiences as a young black man in North America: just as Atlas and Gasuza construct theirs signified through various forms of masculinist 'street-cred'. As a result, this demand for recognition in the public sphere inherently favours masculinist representation and, therefore, privilege. Given that Babaluku emerged as part of Uganda's first hip-hop ensemble the Bataka squad, alongside the acclaimed female rapper Tshila, who later focussed the Bavubuka foundations agenda on gender, Babaluku's articulations suggest the fault of omission, inadvertently rendering gendered power relations as 'invisible ... with women, and things feminine, defined only in relation to the masculine norm' (Cook and Roberts 2000).

Even so, these lived experiences demonstrate specific local performativities contained within hip-hop as globally mediated popular form. Building on these connections, the final sections of this article will contextualise the uses of image in a site of social and economic fragility. In interrogations of the visual post-colony, Mbembé (2001b) and Newell (2013) juxtapose the corporeal and the ineffable: just as the

12 Interview, 22 December 2014. Additionally, all quotes in this chapter are included from this conversation 
mask symbolises the power of the spirits and shades, the use of consumer brands signifies financial success and economic mobility. In the Ugandan hip-hop image, one could replace the spirits and shades Mbembé speaks of with the signs and symbols of hip-hop, both conscious and commercial, such as gilt chains and replicas of automatic rifles, and the red, gold and green of Pan-African emancipation. A final discussion will confirm that strivings towards economic success and social justice originate from a space of common ground, which is wanting something better out of life.

\section{Mastery, deformation, unification}

Baker refers to Franz Fanon's 'dying colonialism' (1965), wherein 'this death of colonialism sounds a note of liberation to which hundreds of millions of formerly colonised, darker peoples of the world can march (1987b, p. 96)'. All is not so sanguine, as neoliberal capitalism has lent itself to a further relegation of the nations and peoples of the Global South, among which Uganda comprises, exacerbating social and economic fragilities. In Uganda, alongside a largely authoritarian government, the oppression previously embodied in colonial subjugation can be supplanted with the reach of capitalism, where one is compelled to be part of this system of fragility in order to survive, whether you choose to be or not. In such sites, the need to attain economic stability occurs often in the most basic sense, in that it is related to survival, revealing thus the obligation to choose capitalism as the only system. Here, individuals and communities are components of a system that requires an accumulation of wealth, couched in terms of political stability and economic development. This is a relationship which Amartya Sen in Development as Freedom elucidates as one between 'commodities and capabilities', which links 'our economic wealth and ability to live as we would like' (2001, p. 13). In a different context, but similar in effect, this connection is that which links art and economics (Baker 1987a), in the form of the 'blues matrix', a network that mediates poverty and abundance (pp. 8-9). These relationships in Uganda manifest themselves cheek-by-jowl: exclusive nightclubs next to shacks used for petty trading, and motorcycle taxis vying for space in traffic jams along with $4 \times 4$ Land Cruisers on potholed roads

Excess as insinuated in the image of Atlas and Gasuza only comes from the realisation that for most there is very little. This response similarly informs Babaluku's activist image: he laughs and says, 'when you think of America you think of beauty, gold etc ... (you think you) got a bit of opportunity ... you don't hear about the nightmare'. A forceful example of this relationship can be found in an unreleased track, a collaboration between Babaluku and Gasuza, called 'Insurgency', a rough cut of which was shared with me. The lyrics are featured in Table 2. A sonic arrangement best described as reminiscent of Nas' 'Illmatic' includes a pared down beat inflected by the notes of a piano, allowing the vocals to dominate the track. This is a powerful critique of patterns of profound disjuncture located in colonial oppression and capitalist exploitation in Uganda, and in Africa. Uttered in 'Insurgency' is a scathing indictment of the 'attitude of passivity in mute indifference/and sometimes a cold complicity' in the face of such circumstances, and a coincident articulation of belonging to and from Uganda and the African continent.

In spite of this powerful lyricism, these apprehendings, variously rendered in excess and in activism, denote an enthrallment. The critical concomitance of excess and activism can be understood through 'mastery of form' and 'deformation of 
Table 2. Gasuza and Babaluku - 'Insurgency'. Unreleased track: Lyrics shared courtesy of the artist

The future will have no pity for those men who

Possessing the exceptional privilege of speaking words of truth to their oppressors

Have taken refuge in an attitude of passivity in mute indifference

And sometimes a cold complicity (chorus)

It's a state of emergency

Can you feel the urgency?

It's a state of emergency

We need an insurgency
Welcome to the sounds from the source of the Nile

God bless all men, women and child

Africa has been poor for a while

The answer lies in the heart of the evil mankind

For how long are we goin' be stuck in the slump

This is our home, got gold, got diamonds, got coffee, got tea, got rubber

Our iron makes steel, so why are we broke

Cus' robbers been takin' it free

Time to start taxin' them

And chargin' them a fee
Doing it for my people

I'm doing this shit for me

God bless Africa

God bless UG

I'm an African

The fight is against the master

Not the one that makes deals with the master

We gotta decide if we wanna move forward

Shut down anything movin' us backwards

(chorus)

It's a state of emergency

Can you feel the urgency?

It's a state of emergency

We need an insurgency

mastery' in an understanding of black popular forms (Baker 1987b). Drawing on Booker T. Washington and W. E. B. DuBois, Baker deploys strategies of discourse: mastery or skill and finesse in the articulation of the spoken word is fairly straightforward, in that it creates a space and audience for these articulations. However, deformation of mastery becomes a transgressive and resistant process where the folk and the popular merge with the terms of high culture. The relationship between mastery and deformation is a complicated discursive relationship, where 'a horizontal axis of mastery implies a coexistent point on a vertical axis of deformation' (Baker 1987, p. 94). Each lends itself to the situation of the other. Looking at hip-hop in the 21st century, one could replace the terms of high culture with those of tremendous monetary acquisition and success, in integration with a mastery of the popular musical and visual. From this perspective, the correspondence of activism and excess is not surprising. Narratives of excess and activism are integral components of hip-hop's expressive culture. They often occur side by side in a simultaneous integration such as in the musical and cultural of oeuvres of superstars such as Tupac, a figure whose image appeared time and time again in recording studios, nightclubs and emblazoned onto taxis and minibuses in Uganda.

In combining excess and activism, the Ugandan hip-hop image frames a 'double consciousness': demonstrative of the global postcolonial, a contested and complicated relationship links colonial histories with contemporary capitalist inequity traversing race, gender and class. Gasuza, Atlas and Babaluku struggled with experiences of marginalisation based on race in North America as young men. Comparably, Uganda's history of violence reveals the hip-hop image to be a semiotic 


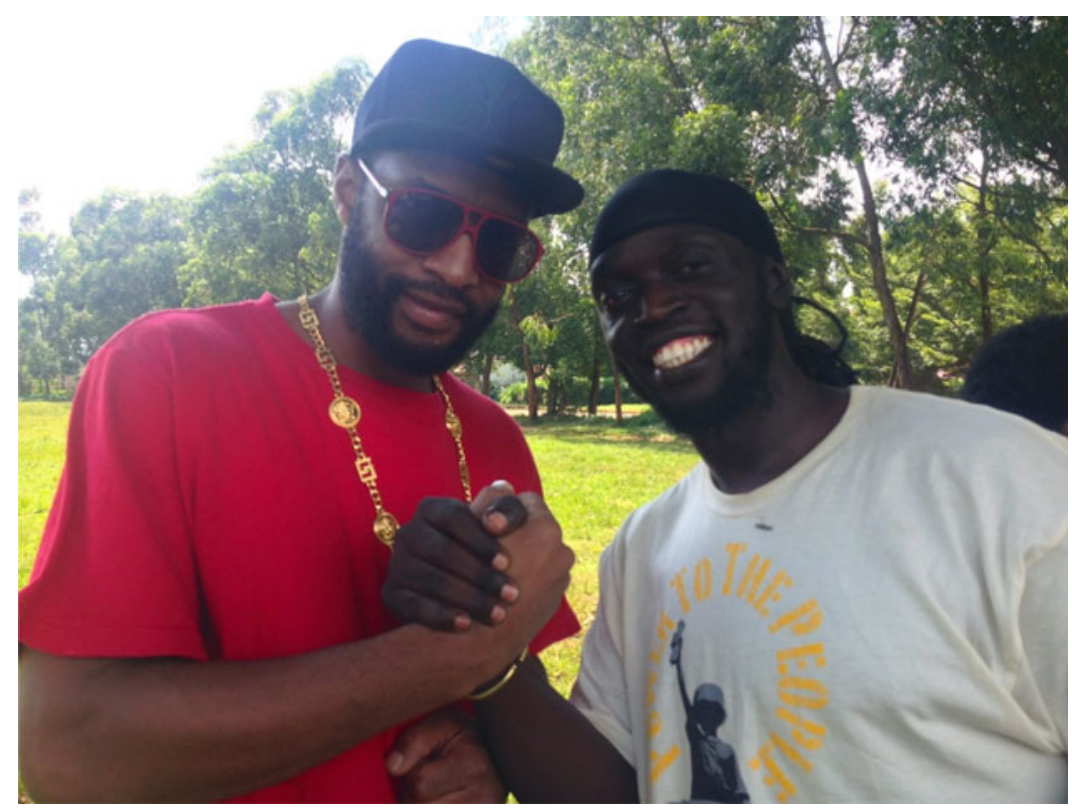

Figure 2. Gasuza and Babaluku at the annual hip-hop summit, Jinja, 2014.

site of masculinity in relation to disempowerment. The representations of masculinity amplified in their image act, as Gilroy asserts in The Black Atlantic, as counteraction and compensation to this dispossession (1993). This is not dissimilar to negotiations of representation in hip-hop as a global cultural phenomenon. The selfdetermination that contours the images of hip-hop success twins discourses of individual agency in neoliberalism, pointing towards the neoliberalisation of culture. At the conjunction of race and gender, Uganda, like elsewhere in Africa, shows that agency and visibility act in concert with structural racism and gender-based hierarchies, abetted by a history of colonialism and neoliberal processes such as globalisation (Steady 2002, 2005; Figure 2).

At this intersection, the twin preoccupations of excess and activism act as a double articulation (Bhabha 1984), both a representation of distinction and one of denial, in an upturning of domination. These manifestations are constructed around an ambivalence, a subterfuge so encoded that it can cynically be considered a 'speculative con' (Smith 2003, p. 681). Variously through activism or excess, the quest for commercial acquisition and cultural influence is uttered in the vocabulary of visible masculinity, leveraging this quest off the very conditions one hopes to escape while simultaneously valorising them. Drawing on Du Bois's 'double consciousness' (2008 [1903]), such preoccupations reveal a 'figurehead of racial double consciousness with a capitalist twist' (Smith 2003, p. 681).

In response to these migrations, a more optimistic reading makes the case for identification through musical cultures, from which in turn emerge contemporary political activisms and creative expressions (Ramnarine 2007, p. 2). Rather than fragmentation, this affects a double consciousness more akin to 'multiple subjectivity' and therefore 'multi-local belonging' (Ramnarine 2007). The Ugandan hip-hop image now acts as a site of myriad unifications: in the American accents that inflect 
Babaluku, Atlas and Gasuza's words, signified in choices of attire, performed via narratives of musical and social lives as men, as Ugandans and Africans. From these tensions emerge 'proto-narratives of possible lives' (Appadurai 1990, p. 299). Acting as both mastery and deformation in challenge of social and economic fragility, the Ugandan hip-hop images of activism and excess hold connections to the past, fashion imaginings of a present and package possibilities for the future. These negotiations find voice in Gasuza's reminiscing about the hip-hop career he almost had, and in Babaluku's yearning for social justice in a homeland where, upon arriving he still found himself cast as the 'Other', and in Atlas' calling out to the affluent neighbourhoods he frequents today while boasting about the 'hood he has successfully evaded.

\section{In conclusion, the 'Gucci-gloved fist'}

In sum, confabulations of excess and activism inform the Ugandan hip-hop image, performed via multiplicities of meaning, contouring a double consciousness that exemplifies the global post-colonial. In the first preoccupation, an aspiration towards economic markers of prestige can only gain credibility in comparison with those with less. In the second, one can only be in a position to challenge inequality after you have the ability to put a square meal a day in your belly. In other words, the luxury of such preoccupations only comes when you occupy a space above those living at subsistence level.

This consideration of image therefore focuses the desire for both economic success and social justice. Providing avenues for the comprehension of 'expressive cultures in its plenitude' (Baker 1987a, p. 1), the Ugandan hip-hop image shows a plenitude of elements such as characters, plots and textual forms, inflecting Gasuza's reminiscences of hip-hop stars and exemplified by a faux Versace chain, Atlas' calling out of places, goods and brands, and Babaluku's construction of hip-hop worldview of resistance to colonial oppression and capitalist exploitation. The Ugandan hip-hop image, therefore, is a tangible act of representation, measured through cultural influence and commercial success, constrained no doubt by the vagaries of Uganda's music industry, but nonetheless as substantial as the weight of Gasuza's faux Versace 'swag', Atlas' weekly appearances on a Monday at Deuces, and in Babaluku's continuing fashioning of Uganda's Lugaflow movement.

Far flung from the genre's origins in the South Bronx, the Ugandan hip-hop image is not fakery in the terms of Kiwaani, as dancehall superstar and now opposition leader and member of Parliament, Bobi Wine ${ }^{13}$ states in the eponymous track released in 2007. The word means 'fake' and has come into use as popular word to describe something that is fraudulent or suspicious. ${ }^{14}$ Instead, in Uganda, a space of profound social and economic fragility, hip-hop forms 'complex, poetically rich, culturally informed imaginings' in negotiation of structural conditions and

${ }^{13}$ Arguably Uganda's most successful popstar, and now an elected representative of a Kampala constituency, won in a landslide victory

${ }^{14}$ Jorg Weingratz cites this song in his paper, 'Fake capitalism? The dynamics of neoliberal moral restructuring and pseudo-development: the case of Uganda' (2010), to show how destructive norms and malpractice in Ugandan society and economy, invoked among the public, a sense of 'moral degeneration', 'moral decay', 'moral decadence', a 'rotten society' and 'fake'. A huge hit, the track went on to win the 2007 Pearl of Africa Music award for the best Afrobeat single. 
subjective perceptions (Comaroff and Comaroff 2001, p. 11). Described as 'new forms of enchantment' (Comaroff and Comaroff 2001, p. 3), local contexts demonstrate how negotiations of global capitalism take novel forms. Arguably, the promises of abundance that define advanced capitalism, which in turn form the weft of hip-hop imagery in general, have circumvented Uganda. At the same time, Uganda remains enmeshed in systemic socioeconomic fragility in relation to neoliberal capitalism. This system is 'powerful and pervasive ... with its own logic and symbols, its own independence relative to any individual' (Taylor 2015, p. 13). Its existence is ubiquitous, traversing both race and gender, and whether people desire or choose to serve as components in this arrangement, they are enmeshed in no small measure. In response, consumers with particular emphasis on the Global South 'trade up' to higher levels of economic mobility. Described by Comaroff and Comaroff as the 'Gucci-gloved fist' (1999, 2001, p. 4), these go hand in hand, as it were, with Adam Smith's 'invisible hand' ([1827] 2010), the metaphor from which capitalism emerges. This process includes aspiration for goods and commodities along with articulations of the terms of acquisition. In these contexts, popular cultures such as hip-hop question a constitutive relationship of production and consumption: they modify how individuals perceive each other, fashion modes of style to provide new ways of individual representation, circumscribing novel forms of public expression (Mbembé 2001a). The Ugandan hip-hop image similarly raises issues of individual representation and choice, demonstrating how local manifestations of global popular cultures such as hip-hop are neither disingenuous nor homogenising in their preoccupations and manifestations.

An interlocution of post-colonial rupture and neoliberal exploitation, image captures actual strivings for economic freedom and social justice. The Ugandan hip-hop image shows an identification and realisation of one's place and role in the world, expressed and articulated through the genre. Both renditions of the Ugandan hip-hop image, of excess and of activism, originate from the same place - they are cast against a reality where most do not have the opportunity for social kinesis and economic acquisition. The Ugandan hip-hop image, consequently, in musical life and in social life, holds its power not through an exactitude of representation. Image acts instead as potent allegory, where excess and activism simultaneously confront and challenge the trauma associated with fragile sites such as Uganda.

\section{References}

Anderson, E. 1994. 'The code of the streets', Atlantic Monthly, 24, pp. 81-94

Annan, J., Blattman, C., Mazurana, D., and Carlson, K. 2011. 'Civil war, reintegration, and gender in Northern Uganda', Journal of Conflict Resolution, 55/6, pp. 877-908

Appadurai, A. 1990. 'Disjuncture and difference in the global cultural economy', Theory, Culture E Society, 7/2, pp. 295-310

Baker, H.A. 1987a. Blues, Ideology, and Afro-American Literature: A Vernacular Theory (Chicago, University of Chicago Press)

Baker, H.A. 1987b. Modernism and the Harlem Renaissance (Chicago, University of Chicago Press)

Baudrillard, J., and Levin, C. 1981. For a Critique of the Political Economy of the Sign (Vol. 262) (St Louis, Telos Press)

Bhabha, H. 1984. 'Of mimicry and man: the ambivalence of colonial discourse', October, 28, pp. 125-33

Björkman-Nyqvist, M. 2013. 'Income shocks and gender gaps in education: evidence from Uganda', Journal of Development Economics, 105, pp. 237-53

Bradley, R.N. 2015. 'Barbz and kings: Explorations of gender and sexuality in hip-hop', in The Cambridge Companion to Hip-Hop, ed. J.A. Williams (Cambridge, Cambridge University Press). pp. 181-91 
Canagarajah, S., Newman, C., and Bhattamishra, R., 'Non-farm income, gender, and inequality: evidence from rural Ghana and Uganda', Food Policy, 26/4, pp. 405-20

Chang, J. 2007. Can't Stop Won't Stop: A History of the Hip-hop Generation (New York, St Martin's Press)

Cheney, C. 2005. Brothers Gonna Work it Out: Sexual Politics in the Golden Age of Rap Nationalism (New York, NYU Press)

Comaroff, J.L., and Comaroff, J. eds. 1999. Civil Society and the Political Imagination in Africa: Critical Perspectives (Chicago, University of Chicago Press)

Comaroff, J., and Comaroff, J.L. eds. 2001. Millennial Capitalism and the Culture of Neoliberalism (Durham, Duke University Press)

Comaroff, J., and Comaroff, J. 2006. 'Reflections on youth, from the past to the postcolony', in Frontiers of Capital: Ethnographic Reflections on the New Economy, (Durham, Duke University Press) pp. 267-81

Cook, J., and Roberts, J. 2000. 'Towards a gendered political economy', in Towards a Gendered Political Economy (London, Palgrave Macmillan), pp. 3-13

Dolan, C. 2013. Social Torture: the Case of Northern Uganda, 1986-2006 (Vol. 4) (Berghahn Books)

Dyson, M.E. 1995. Making Malcolm: The Myth and Meaning of Malcolm X (Oxford, Oxford University Press)

Du Bois, W.E.B. 2008. The Souls of Black Folk (Oxford, Oxford University Press)

Fanon, F. 1952. Black Skin, White Masks (New York, Grove Press)

Fanon, F. 1965. A Dying Colonialism, trans. H. Chevalier (New York, Grove Press)

Fanon, F., Sartre, J.P., and Farrington, C. 1963. The Wretched of the Earth (Vol. 36) (New York, Grove Press)

Ferguson, J. 2006. Global shadows: Africa in the Neoliberal World Order (Durham, Duke University Press)

Finnström, S. 2008. Living with Bad Surroundings: War, History, and Everyday Moments in Northern Uganda (Durham, Duke University Press)

Friedman, J. 1994. 'The political economy of elegance: an African cult of beauty', in Consumption and Identity, ed. J. Friedman (Reading: Harwood Academic), pp. 120-34

Geertz, C. 1973. The Interpretation of Cultures (Vol. 5019) (New York, Basic Books)

Gilroy, P. 1993. The Black Atlantic: Modernity and Double Consciousness (Harvard, Harvard University Press)

hooks, bell (1994). Outlaw Culture: Resisting Representations (New York, Routledge)

Hall, S. 1993. 'What is this "black" in black popular culture?', Social Justice, 20(1/2 (51-52), pp. 104-114

Jameson, F. 1984. 'The politics of theory: ideological positions in the postmodernism debate', New German Critique, 33, pp. 53-65

Jameson, F. 1991. Postmodernism, or, the Cultural Logic of Late Capitalism (Durham, Duke University Press)

Katungi, E., Edmeades, S., and Smale, M. 2008. 'Gender, social capital and information exchange in rural Uganda', Journal of International Development: The Journal of the Development Studies 20(1), pp. 35-52

Lash, S.M., Urry, S.L.J., and Urry, J. 1993. Economies of Signs and Space (Vol. 26) (London, Sage)

Lipsitz, G. 1994. Dangerous Crossroads: Popular Music and the Poetics of Postmodernism (London, Verso)

Lipsitz, G. 2007. Footsteps in the Dark: The Hidden Histories of Popular Music (Minneapolis, University of Minnesota Press)

Lomo, Z., and Hovil, L. 2004. Behind the Violence: Causes, Consequences, and the Search for Solutions to the War in Northern Uganda (Refugee Law Project)

Mamdani, M. 1997. 'Citizen and subject: Contemporary Africa and the legacy of late colonialism', Perspectives on Political Science, 26, p. 120

Mbembé, A. 2001a. 'Ways of seeing: beyond the new nativism. Introduction', African Studies Review, 44(2), pp. 1-14

Mbembé, .A. 2001b. On the Postcolony (Vol. 41) (Berkeley, University of California Press)

McRobbie, A. 1994. Postmodernism and Popular Culture (Hove, Psychology Press)

Mirembe, R., and Davies, L. 2001. 'Is schooling a risk? Gender, power relations, and school culture in Uganda', Gender and Education, 13/4, pp. 401-16

Murray, D.C. 2004. 'Hip-hop vs. high art: notes on race as spectacle', Art Journal, 63/2, pp. 4-19

Newell, S. 2012. The Modernity Bluff: Crime, Consumption, and Citizenship in Côte d'Ivoire (Chicago, University of Chicago Press)

Newell, S. 2013. 'Brands as masks: public secrecy and the counterfeit in Côte d'Ivoire', Journal of the Royal Anthropological Institute, 19/1, pp. 138-54

Ntarangwi, M. 2009. East African Hip Hop: Youth Culture and Globalization (Chicago, University of Illinois Press)

Okello, M.C., and Hovil, L. 2007. 'Confronting the reality of gender-based violence in northern Uganda', The International Journal of Transitional Justice, 1/3, pp. 433-43

Perry, M.D. 2008. 'Global black self-fashionings: Hip-hop as diasporic space', in That's the Joint! The Hip-Hop Studies Reader, ed. M. Forman and M.A. Neal (New York, Routledge), pp. 294-314

Ramnarine, T.K. 2007. Beautiful Cosmos: Performance and Belonging in the Caribbean Diaspora (London, Pluto Press)

Rollefson, J.G. 2017. Flip the Script: European Hip Hop and The Politics of Postcoloniality (Chicago, University of Chicago Press)

Rose, T. 1994. Black Noise: Rap Music and Black Culture in Contemporary America (Middletown, CT, Wesleyan University Press)

Sahle, E.N. 2008. 'Gender, states, and markets in Africa', in Neoliberalism and Globalization in Africa (pp. 71-92) (New York, Palgrave Macmillan) 
Sen, A. 2001. Development as Freedom (Oxford, Oxford Paperbacks)

Singh, S. (forthcoming) "Just be easy, feel the music": branding in the musical and social life of Kampala's hip-hop scene', Journal of East African Literary and Cultural Studies.

Singh-Grewal, S. 2018. 'Hip hop as civil society: activism and escapism in Uganda's hip hop scene', in Songs of Social Protest, ed. A. Dillane, M.J. Power, E. Devereux and A. Haynes (London, Rowman and Littlefield), pp. 288-300

Smith, A. [1827] 2010. The Wealth of Nations: An inquiry into the nature and causes of the Wealth of Nations (Petersfield: Harriman House)

Smith, C.H. 2003. "I don't like to dream about getting paid": representations of social mobility and the emergence of the hip-hop mogul', in That's the Joint! The Hip-Hop Studies Reader, ed. M. Forman and M.A. Neal (New York, Routledge), pp. 672-89

Ssewakiryanga, R. 1999. 'What has become of our teens?'. Popular Culture and the Disciplines. ENRECA Occasional Working Papers, 5, pp. 108-20

Ssewakiryanga, R. 2004. 'New kids on the blocks: African-American music and Uganda youth', CODESRIA Bulletin, 1999(1-2)

Ssewakiryanga, R., and Isabirye, J. 2006. 'From war cacophonies to rhythms of peace: popular cultural music in post-1986 Uganda', Current Writing: Text and Reception in Southern Africa, 18(2), pp. 53-73

Steady, F.C. 2002. 'Global perspectives on black women and the paradox of globalization' Black Women, Globalization, and Economic Justice: Studies from Africa and the African Diaspora, pp. 37-60 (Rochester, Schenkman Books)

Steady F.C. 2005. 'An investigative framework for gender research in Africa in the New Millennium', in African Gender Studies A Reader, ed. O. Oyěwùmí (New York, Palgrave Macmillan)

Taylor, T.D. 2015. Music and Capitalism: a History of the Present (Chicago, University of Chicago Press)

Watts, E.K. 1997. 'An exploration of spectacular consumption: Gangsta rap as cultural commodity', Communication Studies, 48/1, pp. 42-58

Wiegratz, J. 2010. 'Fake capitalism? The dynamics of neoliberal moral restructuring and pseudo-development: the case of Uganda', Review of African Political Economy, 37/124, pp. 123-37 